DOI: https://doi.org/10.34069/AI/2021.47.11.16 How to Cite: Buhaiov, Y.Y., Koretskyi, O.P., Koretska, V.V., Penkov, S.V., Shapar, A.O. (2021). International experience of crime investigation in the field of human trafficking. Amazonia Investiga, 10(47), 161-172. https://doi.org/10.34069/AI/2021.47.11.16

\title{
International experience of crime investigation in the field of human trafficking
}

\section{МІЖНАРОДНИЙ ДОСВІД РОЗСЛІДУВАННЯ ЗЛОЧИНІВ У СФЕРІ ТОРГІВЛІ ЛЮДЬМИ}

Received: September 12, 2021

Abstract

The paper aims to define an effective anti-human trafficking system in Ukraine. On the basis of theoretical information and international experience systematic analysis, the peculiarities of investigating crimes in the field of human trafficking are identified: timely receipt of information concerning crimes commission, assigning a case of human trafficking to an investigator or prosecutor with positive experience in detecting such crimes, cooperation of law enforcement agencies with each other and law enforcement agencies of other states in regard to effective ways of such crimes investigation, an effective system of human trafficking victims support. It is possible to increase the effectiveness of combating human trafficking through activities in the following areas: training of law enforcement officers in accordance with international standards; exchange of experience between Ukrainian law enforcement officers with the employees of relevant institutions of other countries; enshrinement at the statutory level of stricter responsibility for such crimes commission;
Accepted: October 31, 2021

Written by:

Yaroslav Y. Buhaiov ${ }^{68}$

https://orcid.org/0000-0002-0483-0234

Oleh P. Koretskyi ${ }^{69}$

https://orcid.org/0000-0002-2182-1436

Viktoriia V. Koretska ${ }^{70}$

https://orcid.org/0000-0002-5685-5337

Serhii V. Penkov ${ }^{71}$

https://orcid.org/0000-0003-4044-5824

Artem O. Shapar ${ }^{72}$

https://orcid.org/0000-0001-5327-701X

\begin{abstract}
Аннотація
Рівень торгівлі людьми може зростати внаслідок соціально-економічних змін, таких як пандемія COVID-19, зниження матеріального рівня життя населення, підвищення мобільності та міграційних потоків, наявність можливостей для торговців людьми скоювати злочини. Тhe paper aims to визначити ефективну систему боротьби 3 торгівлею людьми в Україні. На основі системного аналізу теоретичних відомостей та міжнародного досвіду визначені особливості розслідування злочинів у сфері торгівлі людьми: своєчасне отримання інформації щодо скоєння злочинів, закріплення за справою щодо торгівлі людьми слідчого чи прокурора 3 позитивним досвідом розкриття подібних злочинів, взаємодія структурних підрозділів правоохоронних органів між собою та 3 правоохоронними органами інших держав щодо ефективних способів розслідування таких злочинів, ефективна система підтримки жертв торгівлі людьми. Підвищити ефективність боротьби 3 торгівлею людьми
\end{abstract}

\footnotetext{
${ }^{68}$ Kharkiv Aviation Squadron, Head of Department, Kharkiv National University V. Karazin, Kharkiv, Ukraine.

${ }^{69}$ Associate Professor of Judiciary, Prosecutor's Office and advocacy Institution of higher education Lviv University business and law, Lviv, Ukraine.

${ }^{70}$ Judge of Kivertsiv District Court, Volyn Region.

${ }^{71}$ Doctor of Law, Professor "Dnipro humanitarian university", Dnipro city, Ukraine.

${ }^{72} \mathrm{PhD}$ of Law, Associate Professor Deputy Director for Educational and Research Activities of the Kryvyi Rih Educational and Scientific Institute Donetsk State University of Internal Affairs, Kryvyi Rih, Ukraine.
} 
monitoring the compliance of the Ukrainian antihuman trafficking system activities with international standards; creation of a comprehensive support system for human trafficking victims.

Key words: exploitation, human trafficking, legislation, responsibility, slavery, Ukraine. можна за допомогою діяльності у таких напрямках: проведення навчання для працівників правоохоронних органів відповідно до міжнародних стандартів; обмін досвідом між українськими працівниками правоохоронних органів 3 працівниками відповідних структур інших держав; законодавче закріплення більш суворої відповідальності за скоєння таких злочинів; моніторинг відповідності діяльності української системи протидії торгівлі людьми міжнародним стандартам; створення системи комплексної підтримки жертв торгівлі людьми. В результаті реалізації вказаних заходів підвищиться рівень безпеки країни та iii соціально-економічний розвиток.

Ключові слова: відповідальність, експлуатація, законодавство, рабство, торгівля людьми, Україна.

\section{Introduction}

Modern society is focused on democratization and humanization, so the topical issues which are to be resolved and improved are the issues related to modern slavery, human trafficking and violence. Human trafficking is a global problem, which is typical for many countries around the world. Crimes in the field of human trafficking are transnational and effectiveness of combating them needs to be increased at the international level. Human trafficking crimes are among the most lucrative ones, and are characterized by the involvement of illegal migration flows. According to the statistics, human trafficking is one of the most lucrative illegal businesses, generating at least $\$ 30$ billion of profits annually (Interpol, 2009).

Currently, the situation in the field of human trafficking crimes and their detection and investigation gets more complicated due to the global crisis caused by the COVID-19 pandemic. The negative global social and economic consequences of the pandemic have increased the human trafficking rate in the world and changed the ways in which such crimes are committed. Human traffickers have started using online technology and other means to recruit and exploit victims. Thus, according to the statistical data for 2020 of the Ministry of Social Policy of Ukraine, 162 people submitted documents in Ukraine to establish the status of a human trafficking victim. Among the people who obtained the status of human trafficking victims there are 28 women, 68 men and one child (a boy). Among them, there were 32 people who were the victims of labor exploitation, 4 people were sexually exploited, 2 people were victims of begging, 4 people were involved in criminal activities, and 55 people were used in armed conflict. The countries exploiting human trafficking victims were the Russian Federation, Ukraine, Lebanon, Italy, the UAE, and Turkey.

The results of Ukrainian sociological research highlight new threats to Ukraine in the field of human trafficking. Thus, over the last 3 years, the number of human trafficking victims has increased to 49 thousand people. Internally displaced persons are the most vulnerable to human trafficking in the eastern Ukraine. The level of awareness among children and young people about the possible ways to protect themselves from human trafficking has increased in comparison to 2015, but it still remains quite low (less than $50 \%$ of the total number of surveyed citizens of Ukraine). Before the beginning of the XXI century the main type of human trafficking was trafficking for the purpose of sexual exploitation of women, but today there is a tendency of other types of human trafficking spread, namely: forced labor, slavery or customs similar to slavery, use in porn trade, forced pregnancy, organ harvesting, human experimentation, use in begging, involvement in criminal activities, use in armed conflicts, adoption for profit, sale of a child. Anyone can become a victim, regardless of his or her age, gender, educational background, social status, citizenship, etc. (Ministry of Social Policy, 2020). 


\section{$\underset{\mathbb{A} M \mathbb{A} Z \mathbb{Z N D A}}{\text { Vmvestiga }}$}

Regarding the investigation of crimes in the field of human trafficking, A. Shevchenko notes that most of them were detected by the employees of the anti- human trafficking units of the National Police (Shevchenko, 2019). The International Labor Organization estimates that at least 2.4 million children and adults suffer from sexual slavery and forced labor (International Labour Organization for Migration, 2006).

The effectiveness of combating human trafficking crimes depends mostly on the professional knowledge and skills of investigators and operational officers involved in the investigation of human trafficking crimes. In addition, there is a lack of comprehensive, thoroughgoing elaboration of theoretical provisions and proposals for improving the investigation of human trafficking (Servitskyi \& Halona, 2021). Therefore, it is relevant and necessary to study the features of the investigation and detection of human trafficking crimes at the international level, which will increase the effectiveness of combating and counteraction to such crimes in Ukraine.

The paper aims to define an effective anti-human trafficking system based on the analysis of the investigation specifics of human trafficking in developed countries and at the international level.

\section{Metodology}

Human trafficking crimes are the subject of research in various scientific fields - law, psychology, sociology, political science. The study of the peculiarities of the human trafficking crimes investigation involves a comprehensive analysis, which includes both special and general theoretical scientific approaches and methods. The general theoretical methods of cognition are as follows: dialectical, systemic methods, as well as the method of classification, grouping and systemic structural approach. The application of the classification method allowed to determine the main types of human trafficking, depending on the purpose of commission of a crime. On the basis of the dialectical method the peculiarities of the development of methods of such crimes detection and investigation, as well as their connection with external factors of influence, such as social, economic and political conditions, are determined. Based on a systematic analysis, the main reasons and conditions of commission of human trafficking crimes are identified. Among the special methods of cognition, such methods as logical-legal and the method of comparative law were applied. On the basis of the logical-legal method the peculiarities of human trafficking crimes investigation and the means of combating and counteracting such crimes are determined. Using the method of comparative law, a comparison was made between the legislative measures used in different countries with the aim to detect, counteract, investigate and combat human trafficking crimes. Conclusions and proposals of scientific research are formulated through the use of the generalization method.

\section{Literature review}

An analysis of international legal acts and many scientific publications helps clarify the nature of human trafficking. It is increasingly considered as an issue of crime prevention. Combating in this case involves the application of criminal punishment, interaction of police units, establishment of urgent and constant exchange of information of operational interest (Dombrovan, 2013).

According to the Protocol on Prevention, Cessation and Punishment for Human Trafficking, Especially concerning Women and Children, supplementing the United Nations Convention "Against Transnational Organized Crime" (Protocol 1433-15, 2000), human trafficking is an act of recruitment, the transportation, transfer, hiding or receipt of persons by threat of force or its use or other forms of coercion, abduction, fraud, deception, abuse of power or vulnerability, or by means bribery, in the form of payments or benefits, to obtain the consent of a person controlling another person (Council of Europe, 2010).

P.V. Horbasenko (2013) notes that human trafficking means the illegal recruitment, transportation, transfer, receipt, hiding of a person, which are carried out for further use for the purpose of involvement in work, sexual exploitation. Sexual exploitation is the illegal involvement of a male or female person, his or her sexual characteristics and abilities, of any age, against his or her will, to satisfy the physiological or psychological needs of another person for obtaining financial or other gain. At the same time, violence is an external intentional and unlawful influence on a person (or group of persons) from other persons, which is carried out against his or her will and can cause him/her organic, physiological or mental trauma, as well as restrict his/her freedom of expression or actions (Serdiuk, 2002). 
Cherechukina \& Yakovenko (2013) defines the main drivers of human trafficking, which include: gender inequality, lack of equal opportunities, economic inequality both within and between states, corruption and vulnerability resulting from inadequate judicial and law enforcement systems, civil instability and failure of states to perform their functions to protect and provide for their citizens. One of the factors contributing to the prosperity of human trafficking is the demand for paid sexual services and cheap manpower resources for construction, manufacturing, industry and the household (Skriabin, 2020).

I. Buresh (2013), distinguishes the following external causes of human trafficking:

- ineffective anti-human trafficking system in the world;

- demand for human trafficking;

- availability of opportunities for human traffickers;

- proposal, availability of potential victims.

N.M. Didyk (2016) distinguishes the following internal preconditions of human trafficking: economic, social, psychological, informational and legal preconditions.

A.O. Nahorna, A.S. Slavko (2020) identify the factors affecting the high rate of human trafficking in Ukraine:

1) increasing of population mobility level;

2) an increase in the number of people living below the poverty line in developing countries;

$3)$ the emergence of internally displaced persons and related labor migration;

4) economic instability, high rate of unemployment;

5) the shadow economy;

6) lack of material income of citizens;

7) social and economic inequality in the country;

8) multi-member families;

9) insufficient awareness in the field of employment abroad.

The factor of low material income of the population, as one of the reasons for the high level of human trafficking crimes, is confirmed by research of scientists. A study by Busza, Castle, and Diarra (2004) has found that Vietnamese migration to Cambodia has been caused by economic factors, a desire to become independent, and dissatisfaction with agricultural work. Chin (2013) notes that Chinese migrants cite the desire to be financially independent as the reason for working in the sex industry. Such studies reveal another reason for high rates of human trafficking, which is that not all of the victims are affected by exploitation and consider themselves to be victims of human trafficking.

The Global Report on Trafficking in Persons (UNODC, 2016b) highlights the main features of the following crimes:

1) the most common forms of such crimes are sexual and labour exploitation;

2) the legislation in regard to human trafficking is at the stage of implementation, which may be associated with a low level of conviction of criminals;

3) $72 \%$ of victims are children and women ( $51 \%$ of women and $28 \%$ of children);

4) in $2012-2014,42 \%$ of victims became victims of human trafficking in their country;

5) a victim and criminal are usually related by origin - cultural or country of residence, which is used to lure victims (UNODC, Global Report on Trafficking in Persons, 2016a).

All investigative situations in criminal proceedings in the field of human trafficking arising at the initial stage of the investigation can be divided into three groups:

1) there are signs of human trafficking and a person who committed it is known;

2) there are signs of human trafficking, but the person who committed it is unknown;

3) there are signs of human trafficking and information about a possible criminal, but the location of the latter is unknown (Law N3739-VI/2011).

N.S. Karpov (2005) identifies the following main elements of the forensic characteristics of human trafficking: the method of committing a crime; place and circumstances of the crime; the time of the crime; tools and means; subject of encroachment; a victim; the identity of a criminal; traces of the crime. A.I. Volkova (2006) provides a more accurate definition of the forensic characteristics of human trafficking, defining it as a multifaceted and complex phenomenon, which embodies all the specific features of this type of crime.

An important aspect in the human trafficking investigation is the ability of an investigator to penetrate into the forensic nature of the crime itself. Achieving the set goal is ensured by timely 


\section{AMAZZOND用}

assignment of a highly qualified investigator or a group of investigators to a specific criminal proceeding. Establishing the primary, initial information obtained during the investigation of human trafficking, in accordance with the elements of its forensic characteristics, is an information outpost that will ensure the further success of the investigation and trial.

An investigator should pay special attention to identifying and studying the circumstances indicating the circumstances of human trafficking. If the situation of human trafficking is favorable, it significantly affects the course and dynamics of the crime itself, which is reflected in the mechanism of the latter. At the same time, it indicates the common factors of the formation and location of trace information of a specific crime. Penetration into the situation and circumstances of the crime leads to a clear understanding of the crime, understanding the internal links between the actions committed by the criminal will, and their reflection from the outside. This understanding makes it possible not only to reproduce the crime pattern imaginatively, but also to understand the motives, which guided a criminal during this crime (Yakymov, 2003).

In addition to public appeals, one of the most effective ways to obtain information on human trafficking is through operational information that comes directly from the sources having access to the criminal environment which can therefore provide the most complete information of operational interest (Dubyna, 2010). This is information obtained from the operational units of the Ministry of Internal Affairs of Ukraine, whose activities are not related to the detection of these criminal offenses. Most of them are operational units of the National Police of Ukraine, which ensure the detection and documentation of criminal offenses and other crimes (Dubyna, 2015).

Sanakoiev (2009) notes that in the direction of counteracting people, interaction at the international level is limited to the implementation of international inquiries and investigative orders in criminal proceedings. For the law enforcement agencies of Ukraine, the development of cross-border and international cooperation in combating organized crime and human trafficking is relevant (Sanakoiev, 2018).

Anti-human trafficking can be traced at different levels: global (UN and its structures, Interpol), regional (OSCE, Council of Europe, EU) and state (state mechanisms of counteraction) (Kraievska, 2015).

The activities of international governmental and non-governmental organizations are an integral factor in the functioning of the modern international anti-human trafficking system. The mechanisms of cooperation between states and representatives of civil society developed within their framework are important for combating human trafficking (Monastyrova, 2018). The first significant steps to combat human trafficking at the international level were taken in the $\mathrm{XX}$ century by such non-governmental organizations such as the International Federation of Abolitionists and the London Committee for the Detection and Elimination of Trafficking in English Girls (Husev, 2008).

Cooperation of human trafficking victims and law enforcement agencies is important for the effective investigation of human trafficking crimes. However, the nature of the crime, the trauma experienced and the fear of repression by human traffickers may be the reason for the victim's refusal to cooperate with lawenforcement authorities. Therefore, the better the system of support, protection and help to victims, the more likely they are to participate in the investigation of such crimes and cooperation with law enforcement agencies (Holmes, 2009).

The nature of the crime and the trauma experienced also require the comprehensive support of the victim (Zimmerman et al, 2003). A human trafficking victim's trauma is usually not the result of a single event, but the result of long lasting actions. Comprehensive support for victims can help make the investigation of such crimes more effective.

The process of human trafficking crimes investigating is complicated by the lack of information on the profile of criminals (Zhang 2009). "There is no standard profile for human traffickers. They range from truck drivers and "thugs" in the villages to labor brokers and police officers. Traffickers are as diverse as the circumstances of their crimes (Feingold 2005, p. 28). Research in the field of human trafficking crimes confirms this fact. Thus, recruiters who forced migrant women to work as prostitutes were their acquaintances, friends, or relatives (Jacobsen \& Skilbrei 2010; Surtees 2008; Vocks $\&$ Nijboer 2000). Molland (2012) notes that women who lived in the same locality or were familiar with the victims were involved in recruiting women to brothels. 
Among the international instruments increasing the effectiveness of human trafficking crimes investigation is the UN Convention against Transnational Organized Crime. UNTOC establishes an international legal framework for international cooperation on transnational relations of organized crime in the field of human trafficking.

The international legal framework includes provisions related to international cooperation for the purpose of confiscation (Article 13); jurisdiction (Article 15); extradition (Article 16); transfer of convicted persons (Article 17); mutual legal assistance (Article 18); joint investigations (Article 19); special methods of investigation (Article 20); transfer of criminal proceedings (Article 21); establishment of a criminal record (Article 22); cooperation of law enforcement agencies (Article 27); as well as the collection, exchange and analysis of information on the nature of organized crime (Article 28). UNTOC member states should cooperate on these issues (David et al, 2010).

Each country in Western Europe has special antihuman trafficking legislation. Since 2000, the United States Department of State has been submitting a report that assesses the "effectiveness" of many countries in the fight against these crimes. Each country belongs to level 1 or 2 , which means that they either fully respect the basic standards set out in the US Law on the Protection of Human Trafficking Victims, or they make significant efforts to do so (Scarpa, 2010).

The EU countries have a legal obligation to cooperate internationally to combat human trafficking, as set out in the case Rantsev vs Cyprus and Russia (GRETA, 2010). The states of the European Union focus on the financial aspects of human trafficking in the Joint Investigation Group (United States Department of State, 2019).

\section{Results and discussion}

Human trafficking is known as one of the third largest international crimes in the world after the illicit drugs and weapons trafficking with an estimated revenue of $\$ 32$ billion annually. Due to the secret nature of the crime, it is difficult to determine the number of victims worldwide (United Nations Security Council, 2017).

The human trafficking crime rate is quite high due to the following factors:
- social and economic reasons (opening of borders, simplification of travelling opportunities; formation of international criminal associations; internationalization of the shadow economy);

- legal and political reasons (inconsistencies of the international legal framework for human trafficking prevention and protection of victims with real conditions, lack of mechanisms for implementing laws; corruption of the relevant law enforcement agencies; inconsistency of migration policy with labor market realities; loyal legislation in regard to prostitution in many countries around the world);

- low material standard of living and searching for the ways to increase income abroad;

- $\quad$ high profits of human traffickers;

- low level of punishment and liability for human trafficking crimes.

Ways to optimize the process of human trafficking investigation can be as follows:

1) assigning a highly qualified investigator (or group of investigators) having experience in similar investigations and practical skills in solving complex tasks to deal with criminal proceedings in relation to human trafficking. This will ensure the choice of the right strategy for the investigation of a particular criminal proceeding and will ensure the selection of the most effective means and methods of investigation;

2) organization of simultaneous investigation, joint coordination activities, cooperation and sharing experiences in the format of online working groups with representatives of law enforcement agencies of Ukraine and representatives of foreign countries, whose powers include the investigation of crimes related to human trafficking;

3 ) the implementation of the above mentioned measures should be constant and comprehensive, and it should be aimed at overcoming the negative phenomena arising during the investigation of human trafficking crimes and court proceedings. This will help to develop an effective strategy to combat human trafficking (Vasylova-Karvatska, 2019).

It is also important to analyze the current antihuman trafficking system and develop preventive measures to reduce this type of crime rate. Preventive measures to combat human trafficking include: 


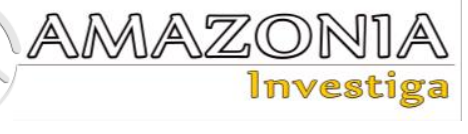

1) prevention, detection and cessation of offenses within the police stations and routes of protection of the security police, in the manner and under the conditions established by the authorities of the National Police;

2) organization of cooperation of the security police with the relevant law enforcement agencies of other states, international organizations;

3) interaction with other defense and law enforcement agencies, public institutions, local governments on issues of maintaining public safety and order;

4) analysis of the causes and conditions of these offenses, their nature, mechanism of effect;

5) submission of notifications to the relevant government and non-government authorities about the identified causes and conditions of offenses and possible ways to eliminate or neutralize them;

6) participation in the development and implementation of state, regional and local programs of security activities and crime prevention;

7) participation in performing expert examinations of legal and socio-economic projects and decisions;

8) participation in legal education, providing consulting assistance to the population on protection against illegal encroachments, etc. (Sachavo, 2004; Holosnichenko, 1998).

In order to determine the ways to optimize the process of human trafficking crimes investigation in Ukraine, it is advisable to analyze the legislation of developed countries in regard to combating these crimes.

In the United States, human trafficking crimes are investigated by human trafficking agents and members of operation teams. Research often begins with:

1) leading discussions with the public;

2) calls to the National Human Trafficking Hotline;

3) notification from a law enforcement agency;

4) notification from a non-governmental organization;

5) prompt measures for victims recovery;

6) appeal to states and community governments (FBI, 2021).

In 2018, the Walk Free Foundation published the Global Slavery Index, which estimated the approach to human trafficking in 167 countries. According to this index, the Netherlands is the only country to receive an "A" grade. This points to the fact that the anti-human trafficking system in the Netherlands complies with international rules and standards.

The Government of the Netherlands has published a national action plan to combat trafficking in human beings "Together against Human Trafficking", which includes the following operative directions:

1) development of a basic approach to combat human trafficking;

2) development of an approach to combat labor exploitation;

3) prevention of victimhood;

4) strengthening the municipal approach to combat human trafficking;

5) information sharing.

The peculiarity of the investigation of human trafficking in the Netherlands is that at least one senior prosecutor focuses on human trafficking in each of the regions of public prosecution, as well as at the national level. In total, about 20 prosecutors in the Netherlands specialize in human trafficking. There is a regular experience and knowledge sharing between them in regard to such crimes investigation. There are also investigative SZW inspections specializing in labor exploitation. They may conduct criminal investigations of trafficking in human beings with the aim of labour exploitation in cooperation with a prosecutor. There are also judges specializing in human trafficking who work in several courts of the Netherlands. Among 180200 judges, about 20 of them hear human trafficking cases. They were trained at the Judicial Training Center in the field of human trafficking (European Commission, 2018).

Another country with a high rate of human trafficking is Italy, which in 2018 was among the five EU member states with the highest number of registered human trafficking victims.

Greece, the Czech Republic and Hungary are also among the EU countries with the similar statistics. According to the index of the US State Department report, Italy belongs to the second level of compliance with anti-human trafficking standards. That is, the anti-human trafficking system in Italy does not fully meet international standards. GRETA recognized the improvement in the fight against human trafficking in Italy in 2019. The Italian government has increased funding for anti-human trafficking projects aimed at protection of unaccompanied children who have been trafficked in Italy. In Italy, improvements have been made in the provision 
of assistance to victims and funding for victims and human rights groups has increased (Fontana, 2021).

According to Swedish law, prostitution is defined as a form of male violence against women, and under Section 11 of the Swedish Criminal Code, "a person who acquires casual sex in exchange for payment will be fined or sentenced to a maximum of six months for obtaining sexual services" (Press releases 2002-2006, 2006). This approach is based on the fact that liability for the use of sexual services will reduce the demand for such services, and consequently reduce the profitability of prostitution, which will have a positive impact on reducing the level of human trafficking with the aim of sexual exploitation.
For today, more than thirty countries have adopted a type of extraterritorial legislation allowing a country to prosecute its citizens for crimes committed against children in another country (Svensson, 2006).

According to the UK Sexual Offenses Act 2003, section 72 , individuals can be prosecuted for a sexual offense which is considered as a criminal offense in both countries (Legislation, 2003).

Similarly, Australia has adopted the Amendments to Crime (Child Sex Tourism) Act 1994 No. 105, 1994, which punishes its citizens for having sex with a child under the age of 16 beyond the territory of the country (Aronowitz, 2009).

Table 1.

Human trafficking legislation of developed countries.

\begin{tabular}{|c|c|c|c|c|}
\hline No. & Country & Legislation & Peculiarities & Responsibility \\
\hline 1 & Italy & $\begin{array}{l}\text { Human trafficking in } \\
\text { any form is prohibited } \\
\text { in Italy under Law No. } \\
\text { 228, } 2003 \text { "On } \\
\text { Measures to Combat } \\
\text { Human Trafficking". } \\
\text { Law No. } 75 \text { "On } \\
\text { Prostitution and } \\
\text { Combating } \\
\text { Prostitution } \\
\text { Exploitation by Third } \\
\text { Parties" } \\
\text { Law No. 269 "On } \\
\text { Combating } \\
\text { Prostitution of Minors, } \\
\text { Pornography, Sex } \\
\text { Tourism and Other } \\
\text { Modern Forms of } \\
\text { Slavery". }\end{array}$ & $\begin{array}{l}\text { According to the Italian } \\
\text { Criminal Procedural Code } \\
\text { crimes of this category } \\
\text { are investigated by the } \\
\text { District Office for } \\
\text { Combating Organized } \\
\text { Crime (Direzioni } \\
\text { Distrettuali Anti-mafia). }\end{array}$ & $\begin{array}{l}\text { Responsibility - } \\
\text { imprisonment for a term } \\
\text { of } 8 \text { to } 20 \text { years). } \\
\text { Human trafficking } \\
\text { victims can participate } \\
\text { in social assistance and } \\
\text { integration programs; } \\
\text { they are given access to } \\
\text { education and } \\
\text { employment regardless } \\
\text { of whether they wish to } \\
\text { testify against human } \\
\text { traffickers or not. }\end{array}$ \\
\hline 2 & Sweden & $\begin{array}{l}\text { The Swedish model of } \\
\text { combating prostitution } \\
\text { is to criminalize the } \\
\text { activities of souteneurs } \\
\text { and consumers of } \\
\text { prostitution with the } \\
\text { simultaneous abolition } \\
\text { of criminal and } \\
\text { administrative liability } \\
\text { for the prostitutes } \\
\text { themselves. }\end{array}$ & $\begin{array}{l}\text { In every major city of } \\
\text { Sweden there is a special } \\
\text { police group to combat } \\
\text { prostitution and human } \\
\text { trafficking. This group } \\
\text { monitors street } \\
\text { prostitution, websites } \\
\text { with sales advertisements, } \\
\text { and monitors suspicious } \\
\text { activity in hotels and } \\
\text { apartments. }\end{array}$ & \\
\hline 3 & $\begin{array}{l}\text { The } \\
\text { Netherlands }\end{array}$ & $\begin{array}{l}\text { Since October } 2000 \mathrm{p} \text {. } \\
\text { the sex industry in the } \\
\text { Netherlands has been } \\
\text { decriminalized. Due to } \\
\text { prostitution } \\
\text { decriminalizing, }\end{array}$ & $\begin{array}{l}\text { In the Netherlands, an } \\
\text { active educational work } \\
\text { among the population on } \\
\text { the problem of human } \\
\text { trafficking is carried out. } \\
\text { The government is }\end{array}$ & $\begin{array}{l}\text { Responsibility: The } \\
\text { criminal code of this } \\
\text { country provides for } \\
\text { punishment for any } \\
\text { person who applies } \\
\text { coercion or threat of }\end{array}$ \\
\hline
\end{tabular}


introducing a licensing system for brothels, and improving the working conditions of sex workers, this area of activities has become less accessible to criminal elements. funding for a national information campaign to prevent human trafficking for the purpose of sexual exploitation.

The law provides assistance for victims who prefer to file a lawsuit against human traffickers, provides protection and shelter, and authorizes amendments to immigration laws providing for exemption from immediate deportation and assigning refugee status, followed by a permanent residence permit after three years of stay in the territory of the country. (developed by the authors)

Thus, the analysis of foreign legislation on human trafficking allowed to identify different approaches to combating this type of crime. It should be noted that the Swedish model of combating prostitution and the experience of the Netherlands in combating human trafficking is quite specific and is conditioned by the general socio-economic situation and migration policy. At the same time it is advisable to pay attention to the support system for human trafficking victims in developed countries. Thus, comprehensive support for victims, providing them with protection and conditions for comfortable accommodation, permission to stay in the country contribute to the effectiveness of detecting crimes related to human trafficking.

To increase the efficiency of human trafficking crimes investigation, it is advisable to work in the following areas:

1) Increasing the efficiency of law enforcement officers activities by conducting training in accordance with international standards;

2) Sharing experience between Ukrainian law enforcement officers and employees of relevant authorities of other states, which demonstrate high efficiency in detecting human trafficking crimes;

3) Legislative enshrinement of responsibility for the commission of human trafficking crimes and for the use of services of human trafficking victims (for example, using the experience of Sweden in establishing responsibility for the use of services in the sex industry);

4) Monitoring the compliance of the Ukrainian anti-human trafficking system with international rules and standards;

5) Creation of a comprehensive support system for human trafficking victims at the state level;

6) Increasing funding for human trafficking victims support.

The implementation of these measures will increase the efficiency of the investigation of crimes in the field of human trafficking, reduce the level of human trafficking in Ukraine. Such changes can have a positive impact on the socioeconomic stability of the state.

\section{Conclusion}

The high rate of human trafficking crimes becomes a threat to the security of every state and its population. The aim of the article is to determine an effective anti-human trafficking system in Ukraine. It is determined that the main reasons for the increase in human trafficking are: low material standard of living, negative social and economic consequences of COVID-19 
pandemic, increased population mobility, low level of effectiveness in combating human trafficking at the state level, poor punishment for human trafficking crimes. The effectiveness of human trafficking crimes investigation is influenced by such factors as timely receipt of information on the commission of crimes, assigning an investigator or a prosecutor with positive experience in detecting such crimes, interaction of law enforcement agencies with each other on effective investigation of such crimes, an effective support system for human trafficking victims. Possible ways to increase the effectiveness of the anti-human trafficking system are as follows: training for law enforcement officers concerning investigation of human trafficking crimes in accordance with international standards; sharing experience between Ukrainian law enforcement officers and employees of relevant institutions of other states, which demonstrate the high efficiency of human trafficking crimes investigation; legislative enshrinement of stricter responsibility for committing human trafficking crimes; monitoring the compliance of the Ukrainian antihuman trafficking system with international rules and standards; creation of a system of comprehensive support for human trafficking victims. Implementation of these measures can increase the safety level of the state, which will have a positive impact on the development of the country.

\section{References}

Aronowitz, A. (2009). Human Trafficking, Human Misery: The Global Trade in Human Beings. Praeger Publishers, Westport, CT.

Buresh, I.V. (2013). State regulation in the field of combating human trafficking in Ukraine. Investments: Practice and Experience, 7, 115118. (In Ukrainian).

Busza, J. (2004). Sex work and migration: The dangers of oversimplification. Health and Human Rights 7:231-49. Retrieved from https://www.bmj.com/content/328/7452/1369.

Cherechukina, L.V., \& Yakovenko, M.O. (2013). Detection and Investigation of Crimes Related to Trafficking in Human Beings, 135. (In Ukrainian).

Chin, C. (2013). Cosmopolitan sex workers: Woman and migration in a global city. New York, NY: Oxford University Press. Retrieved from

https://oxford.universitypressscholarship.com/ view/10.1093/acprof:oso/9780199890910.001. 0001/acprof-9780199890910.

Council of Europe (2010). Opinion No. 6/2010 of the Group of Experts on Trafficking in Human Beings of the European Commission: On the
Decision of the European Court of Human Rights in the Case of Rantsev v. Cyprus and Russia. Group of Experts on Action against Trafficking in Human Beings (GRETA). Recovered from https://www.coe.int/t/democracy/migration/bo dies/greta_en.asp.

David, P. et al. (2010). ASEAN Handbook on International Legal Cooperation in Trafficking in Persons Cases. Jakarta: ASEAN.

Didyk, N.M. (2016). Causes of human trafficking. Personality and society: methodology and practice of modern psychology, 102-105. (In Ukrainian). Retrieved from https://www.lvduvs.edu.ua/documents_pdf/bib lioteka/nauk_konf/04_12_2020.pdf

Dombrovan, O.I. (2013). Interaction of Ukrainian law enforcement agencies with EU law enforcement agencies in detecting and investigating human trafficking and illegal migration, 53-56. (In Ukrainian). Retrieved from

https://www.lvduvs.edu.ua/documents_pdf/bib lioteka/nauk_konf/04_12_2020.pdf

Dubyna, V.I. (2010). Current trends in combating human trafficking. Current issues of preventing and combating trafficking in human beings, 1921. (In Ukrainian). Retrieved from http://univd.edu.ua/uk/dir/401/materialinaukovo-praktichnih-konferentsiy-seminarivtoshcho\#2010

Dubyna, V.I. (2015). Operational development of traffickers for women for the purpose of sexual exploitation. Investigative prevention of corruption and corruption-related offenses: materials of the round table, 75-80. (In Ukrainian). Retrieved from http://elar.naiau.kiev.ua/bitstream/123456789/ 7936/1/\%D0\%9E\%D0\%BF\%D0\%B5\%D1\%8 0\%D0\%B0\%D1\%82\%D0\%B8\%D0\%B2\%D0 $\% \mathrm{BD} \% \mathrm{D} 0 \% \mathrm{BE}-$

$\% \mathrm{D} 1 \% 80 \% \mathrm{D} 0 \% \mathrm{BE} \% \mathrm{D} 0 \% \mathrm{~B} 7 \% \mathrm{D} 1 \% 88 \% \mathrm{D} 1 \%$ 83\%D0\%BA\%D0\%BE\%D0\%B2\%D0\%B5_p 074-078.pdf

European Commission. (2018). Together Against Trafficking in Human Beings: Member States: Netherlands. Recovered from https://ec.europa.eu/anti-trafficking/memberstates/netherlands_en.

FBI. (2021). Human Trafficking. Recovered from https://www.fbi.gov/investigate/violentcrime/human-trafficking

Feingold, D. (2005). Human trafficking. Foreign Policy September, 26-32.

Fontana R. (2021). The fight against human trafficking in Italy. Borgenproject. Recovered from https://borgenproject.org/humantrafficking-in-italy/.

Holmes, P. (2009). Manual for Law Enforcement Officers on Detection and Investigation of Trafficking-related Crimes. International Organization for Migration (IOM), Kyiv, 4. 


\section{AMA}

Holosnichenko, I.P. (1998). Administrative law of Ukraine (main categories and concepts). State Tax Administration of Ukraine; Ukrainian Financial and Economic Institute, 109. (In Ukrainian). Retrieved from https://scholar.google.com.ua/citations?user=X qrJWAYAAAAJ\&hl=ru

Horbasenko, P.V. (2013). General provisions of the methodology of investigation of human trafficking, 22. (In Ukrainian). Retrieved from https://dspace.nlu.edu.ua/handle/123456789/14 132.

Husev, L.Yu. (2008). Combating Trafficking in Women: History and Current Situation in Russia and the Shanghai Cooperation Organization, 278 p. (In Russian). Retrieved from http://www.irbis-nbuv.gov.ua/cgibin/irbis_nbuv/cgiirbis_64.exe?C21COM=S\&I $21 \mathrm{DBN}=\mathrm{EC} \& \mathrm{P} 21 \mathrm{DBN}=\mathrm{UJRN} \& \mathrm{~S} 21 \mathrm{FMT}=\mathrm{JW}$ U_B\&S21ALL=\%28\%3C.\%3EU\%3D\%D0\% A5881.9\%284\%D0\%A3\%D0\%9A\%D0\%A0\% $29113.4 \% 20 \% \mathrm{D} 1 \% 8 \mathrm{~F} 431 \% 280 \% 29 \% 3 \mathrm{C} . \% 3 \mathrm{E}$ $\% 29 \& Z 21 \mathrm{ID}=\& S 21 \mathrm{SRW}=\mathrm{AVHEAD} \& \mathrm{~S} 21 \mathrm{SR}$ $\mathrm{D}=\mathrm{UP} \& \mathrm{~S} 21 \mathrm{STN}=1 \& \mathrm{~S} 21 \mathrm{REF}=10 \& \mathrm{~S} 21 \mathrm{CNR}=$ 20

International Labour Organisation for Migration (IOM). (2006). Global Estimates and Trends. Retrieved from https://publications.iom.int/books/managedmigration-and-labour-market-health-sector

Interpol (2009). Internet Posting. Retrieved from https://www.interpol.int/Crimes/Cybercrime/C ybercrime-operations

Jacobsen, \& C. Skilbrei, M. (2010). Reproachable victims? Representations and selfrepresentations of Russian women involved in transnational prostitution. Ethnos, 75, 190-212. Retrieved from https://www.tandfonline.com/doi/abs/10.1080/ 00141841003764013

Karpov, N.S. (2005). Forensic characteristics of human trafficking. University Scientific Notes, 3 (15), 268-273. (In Ukrainian).

Kraievska, O. (2015). International experience in combating the global problem of human trafficking. Bulletin of Lviv University. Series: International Relations. 37, 3, 82-89. (In Ukrainian).

Law 228/2003. Law 228 on Measures against Trafficking in Persons. 11 August 2003. Retrieved from https://www.legislationline.org/documents/id/4 963.

Law 269/1998. Law on Measures against the prostitution of minors, pornography, sex tourism and other contemporary forms of slavery, 3 August 1998. Retrieved from https://www.legislationline.org/documents/id/5 089.

Law N3739-VI. (2011). The Law of Ukraine on Trafficking in Human Beings. 20 September 2011. Retrieved https://imzo.gov.ua/protidiya-torgivlilyudmi/normativna-baza/zakonodavchi-aktishhodo-protidiyi-torgivli-lyudmi-seksualniyekspluatatsiyi-ta-nasilstva/.

Legislation (2003) UK Sexual Offences Act. article 72. Recovered from https://www.legislation.gov.uk/ukpga/2003/42/ section $/ 72$

Molland, S. (2012). The perfect business? Antitrafficking and the sex trade along the Mekong. Honolulu, HI: University of Hawaii Press. Retrieved from https://hawaii.universitypressscholarship.com/ view/10.21313/hawaii/9780824836108.001.00 01/upso-9780824836108.

Monastyrova, E. (2018). Activities of international non-governmental organizations to combat human trafficking. Bulletin of Lviv University. Series: Philosophical and Political Sciences, 16, 30-173. (In Ukrainian).

Nahorna, A.O., \& Slavko, A.S. (2020). Trafficking in human beings: a history of counteraction at the universal and regional levels. Reforming the legal system in the context of European integration processes, 1, 159-163. (In Ukrainian). Retrieved from https://essuir.sumdu.edu.ua/handle/123456789/ 78950.

Press releases 2002-2006. (2006). Ministry of Industry, Employment and Communications press releases. Retrieved from https://www.government.se/49b73d/contentass ets/e2ec94e2b84e4fb8a2310ba2fd46c720/press -releases-2002-2006-from-the-ministry-ofindustry-employment-and-communications

Protocol 1433-15 (2000). To Prevent, Suppress and Punish Trafficking in Persons, Especially Women and Children, supplementing the United Nations Convention against Transnational Organized Crime. 15, November, 2000 Retrieved from https://zakon.rada.gov.ua/laws/main/995_791.

Sachavo, A.G. (2004). Administrative and legal bases of activity of private security structures and their interaction with the police of Ukraine, K.: Nauk. World, 163 p. (In Ukrainian).

Sanakoiev, D.B. (2009). Investigation of trafficking in human beings by organized groups. Dnepropetrovsk: DDUVS. (In Ukrainian). Retrieved from https://scholar.google.com.ua/citations?view_o $\mathrm{p}=$ view_citation\&hl=ru\&user $=\mathrm{cJ} 67 \mathrm{U} 0 \mathrm{UAAA}$ AJ\&citation_for_view=cJ67U0UAAAAJ:d1gk VwhDpl0C.

Sanakoiev, D.B. (2018). Regulatory and legal support of cross-border cooperation in combating human trafficking. Scientific Papers of the Legislation Institute of the Verkhovna Rada of Ukraine, 1, 46-52. (In Ukrainian). Retrieved from https://scholar.google.com.ua/citations?view_o $\mathrm{p}=$ view_citation\&hl=ru\&user $=\mathrm{cJ} 67$ U0UAAA 
AJ\&citation_for_view=cJ67U0UAAAAJ:kNd YIx-mwKoC.

Scarpa, S. (2010). Fighting Against Human Trafficking for Commercial Sexual Exploitation: The Actions in Western Europe. Revue internationale de droit pénal, 81, 563-587. Retrieved from https://doi.org/10.3917/ridp.813.0563

Serdiuk, L.V. (2002). Violence: criminological and criminal law research. Moscow: Yurlitinform, 384. (In Russian).

Servitsky, I., \& Galona, I. (2021). Tactics for finding persons involved in human trafficking. Forensics, 2. https://doi.org/10.32849/26635313/2021.2.49.

Shevchenko, A. (2019). Trafficking in human beings in Ukraine: almost 300 crimes have been detected since the beginning of the year. (In Ukrainian). Ukrinform. Recovered from https://www.ukrinform.ua/rubricsociety/2801788-torgivla-ludmi-v-ukraini-zpocatku-roku-viavili-majze-300-zlociniv.html.

Skriabin, O.M (2020). Features of the investigation of crimes in the field of trafficking in human beings in criminal proceedings. Law and Public Administration, 4, 134-138. (In Ukrainian). https://doi.org/10.32840/pdu.2020.4.19.

Surtees, R. (2008). Traffickers and trafficking in Southern and Eastern Europe. European Journal of Criminology 5, 39-68. Retrieved from https://journals.sagepub.com/doi/10.1177/1477 370807084224.

Svensson, N. (2006). Extraterritorial Accountability: An Assessment of the Effectiveness of Child Sex Tourism Laws. Loyola of Los Angeles International and Comparative Law Review, 28, 641-664. Retrieved from http://ilr.lls.edu/documents/Article6Svensson_ 000.pdf.

United Nations Security Council. (2017) S/RES/2388- Fight against human trafficking in Libya: EU sanctions six human traffickers and smugglers in line with UN decision. Retrieved from

https://www.consilium.europa.eu/en/press/pres s-releases/2018/06/14/fight-against-humantrafficking-in-libya-eu-sanctions-six-human- traffickers-and-smugglers-in-line-with-undecision/.

United States Department of State. (2019). Trafficking in Persons Report - Libya. Recovered from https://ly.usembassy.gov/2019-trafficking-inpersons-report-libya/.

UNODC (2016a). Research on Trafficking in Persons. Recovered from https://www.unodc.org/unodc/ru/data-andanalysis/tip.html.

UNODC. (2016b). Global Report on Trafficking in Persons, Vienna, UNODC; New York, United Nations. Recovered from https://www.unodc.org/documents/data-andanalysis/glotip/2016_Global_Report_on_Traffi cking_in_Persons.pdf.

Vasylova-Karvatska, O.V. (2019). Forensic aspect of the investigation of human trafficking. Problems of law enforcement, 4 (25). https://doi.org/10.32836/2521-6473-2019-4140-144.

Vocks, J., \& Nijboer, J. (2000). The promised land: A study of trafficking in women from Central and Eastern Europe to the Netherlands. European Journal of Criminal Policy and Research 8, 379-88. Retrieved from https://link.springer.com/article/10.1023/A:100 8785214932.

Volkova, A.I. (2006). The structure of the forensic characteristics of human trafficking. Actual problems of the state and law, 27, 174-181. (In Ukrainian).

Yakymov, I.N. (2003). Forensic science. Guide to Criminal Technique and Tactics. New edition reprinted from the 1925 edition, 75. (In Russian).14. Retrieved from http://lawlibrary.ru/izdanie43378.html

Zhang, S. (2009). Beyond the "Natasha" story: A review and critique of current research on sex trafficking. Global Crime 10, 178-95. Retrieved from

https://www.tandfonline.com/doi/full/10.1080/ 17440570903079899.

Zimmerman, C. et al. (2003). The Health Risks and Consequences of Trafficking in Women and Adolescents: Findings from a European Study. London, London School of Hygiene and Tropical Medicine, p. 23. 